\title{
Estimation of Microbial Air Contamination of Operation Theaters by Settle Plate Method at Tertiary Care Hospital, Aurangabad, India
}

\author{
Shraddha Naik*, H.S. Ghogare and M.H. Bhalchandra
}

Department of Microbiology, MGM Medical College and Hospital, Aurangabad, India

*Corresponding author

\begin{abstract}
A B S T R A C T
Keywords

Settle plate method,

Nosocomial

infection, Operation

theatre air quality

Article Info

Accepted:

10 December 2017

Available Online:

10 January 2018

Bacterial contamination of operation theatres is a major risk factor for increased incidence of surgical site and nosocomial infections in hospitals. Now a day the evaluation of the level of microbial air contamination in places at risk is considered to be a basic step towards prevention. The main aim of the study was to estimate microbial air contamination of operation theatres in our hospital by settle plate method (Passive sampling). Objective of the study was to monitor quality of air in the form of bacterial load in operation theatres. Ten operation theatres, one cath lab and one cardiac OT (total 12) were studied for microbial air contamination by settle plate method once in a month for 6 months. Total 72 settle plates were studied from Jan 2017 to June 2017. The growth was identified by standard microbiological procedure. Even a single colony of pathogen such as Staphylococcus aureus, Pseudomonas, fungus is taken as unsatisfactory. For other bacteria colony counts less than 30 are taken as satisfactory. Out of 72 settle plates, three were reported as unsatisfactory. All these three plates were showing growth of staphylococcus aureus.
\end{abstract}

\section{Introduction}

The concentration of microorganisms in atmosphere can have a direct effect on human health and environment. Microbial contamination of operation theatres is a major risk factor for increased risk of surgical site and nosocomial infections in hospital (Bhalla et al., 2007). Evaluation of level of air microbial contamination of operation theatres is considered to be a basic step towards prevention (Sabharwal and Sharma, 2015). Air sampling gives idea about the sterility conditions in operation theatres. Air samples can be collected in two ways: 1) by active air sampler. 2) By passive air sampling (settle plates).

In this study passive air sampling was performed using settle plate method. It is a simple and inexpensive, economical readily available method. It is said to produce the circumstances of infection by dust particles sedimenting in to the wound better than a slit sampler. Settle plates reflect the bacterial load nearest the operative site without creating any turbulence. It predicts the likely contamination rate at the surgical site, as it allows a direct 
measure of the number of organisms settling on the surfaces (Patwardhan and Patwardhan, 2017).

The aim of the study was to estimate microbial air contamination of operation theatres in our hospital by settle plate method (Passive sampling). And the objectives include monitoring quality of air in the form of bacterial load in operation theatres.

\section{Materials and Methods}

The study was carried out in Department of Microbiology, MGM Medical College and Hospital from Jan 2017 to June 2017.

Ten operation theatres, one Cath lab, one Cardiac OT (total 12) were studied for microbial air contamination once in a month for six months.

5\% sheep blood agar plates were used after sterility testing. The plates were transported to operation theatres. The plates were labelled with theatre number, time and date of sample collection.

Plates were exposed to air by placing them with the agar surface upward on operation table/ procedure table for one hour when there was no operative procedure going on. Then the plates were sending to the microbiology department, taking all aseptic precautions. These plates were then incubated overnight at $37^{\circ} \mathrm{C}$. Next day colonies were counted if any. These colonies were assessed for growth of potential pathogenic bacteria by colony characteristics, haemolysis pattern and microscopic examination of Gram stained smears. Identification was done by using standard bacteriological techniques (WHO, 1991).

Even a single colony of a pathogen such as Staphylococcus aureus, Pseudomonas aeuroginosa or fungus was considered as unsatisfactory. For other organisms colony count up to 25 was taken as satisfactory.

The formula used is Number of bacteria settling on 1 square meter of medium per minute $=$ Number of such particles per 0.3 cubic meter of air.

In case of neurosurgery OT satisfactory colony count was up to 5 .

Report was given as satisfactory/unsatisfactory.

If unsatisfactory, OT in charges were advised to follow work instructions for cleaning as per institutional protocol and to carry out repeat fumigation.

\section{Results and Discussion}

Total 72 plates were studied, out of which 3 were reported as unsatisfactory. All these three plates were showing growth of Staph aureus, Out of these three isolates one isolate was MRSA. (Methicillin resistant Staph aureus) The three unsatisfactory settle plates were from OT no. 6, 7 and 8.

The microbiological quality of air in OT depends on the infection control practices taken for the maintenance of operation theatres. In our study out of 72 settle plates only 3 were unsatisfactory, which indicates good infection control practices in our hospital. All of the 3 settle plates were showing growth of Staphylococcus aureus which is in concordance with the studies of Sabharwal and Sharma (2015), Kasdekar et al., (2016). Different studies showed higher concentrations of cocci due to lower susceptibility of organisms to environmental stress due to the presence of pigments and higher peptidoglycan in their cell wall preventing them from drying and heat stress (Raymond et al., 2001). 


\section{Repeat fumigation / fogging were advised in the unsatisfactory reported OTs}

\section{\begin{tabular}{|l|l|l|} 
Total number of settle plates studied & Reported as unsatisfactory & Percentage
\end{tabular} \\ \begin{tabular}{|l|l|l}
\hline 72 & 3 & $4.16 \%$
\end{tabular}}

In our study, not a single plate showed growth of pseudomonas or fungus.

There are no universal guidelines about the concept of regular monitoring and sampling but till that time continuous surveillance by infection control team will provide safe environment for surgical patients.

In conclusion, air quality of operation theatre is important and cannot be neglected in reference to hospital acquired infections and surgical site infections.

\section{Acknowledgement}

Authors are thankful to Dean, M.G.M. Medical College, Aurangabad for granting the permission for this work

\section{References}

Bhalla A., Aron D, and Donskey C. Staphylococcus aureus intestinal colonization is associated with increased frequency of S. aureus on skin of hospitalized patients. BMC Infect. Dis., 7(1): 1; 2007.

Kasdekar, M., Duthade M, Damle A et al.,; Air Quality Monitoring of Operation Theaters in Government Medical College and Hospital, Aurangabad. Int.J.Curr.Microbiol.App.Sci. 5(6): 42 49; 2016.

Patwardhan, N., and Patwardhan S., Hospital - Associated Infections: Epidemology Prevention and Control; $2^{\text {nd }}$ ed. Jaypee Publisher; 2017.

Raymond, D., Pelletier S, Crabtree T et al.,; Surgical infection and the aging population. Am. Surg., 67(9): 827-832; 2001.

Sabharwal, R., and Sharma R; Estimation of microbial air contamination by settle plate method: are we within acceptable limit. Sch. Acad. J. Biosci., 3(8): 703707.

WHO; Basic laboratory procedures in clinical bacteriology. Geneva, 1991.

\section{How to cite this article:}

Shraddha Naik, H.S. Ghogare and Bhalchandra, M.H. 2018. Estimation of Microbial Air Contamination of Operation Theaters by Settle Plate Method at Tertiary Care Hospital, Aurangabad, India. Int.J.Curr.Microbiol.App.Sci. 7(01): 1059-1061.

doi: https://doi.org/10.20546/ijcmas.2018.701.127 